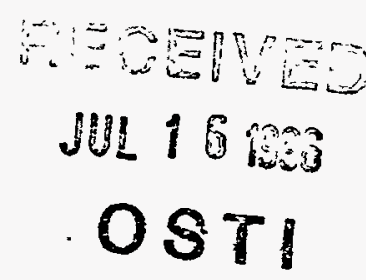

\title{
AFBC Co-Firing of Coal and Hospital Waste
}

\section{Quarterly Report}

August - October 1995

James M. Stuart

March 1996

Work Performed Under Contract No.: DE-FG21-91MC27205

For

U.S. Department of Energy

Office of Fossil Energy

Morgantown Energy Technology Center

Morgantown, West Virginia

By

Donlee Technologies, Incorporated

York, Pennsylvania

DISTREITION OF THIS DOCUMENT IS UNLMITED 


\section{DISCLAIMER}

This report was prepared as an account of work sponsored by an agency of the United States Government. Neither the United States Government nor any agency thereof, nor any of their employees, makes any warranty, express or implied, or assumes any legal liability or responsibility for the accuracy, completeness, or usefulness of any information, apparatus, product, or process disclosed, or represents that its use would not infringe privately owned rights. Reference herein to any specific commercial product, process, or service by trade name, trademark, manufacturer, or otherwise does not necessarily constitute or imply its endorsement, recommendation, or favoring by the United States Government or any agency thereof. The views and opinions of authors expressed herein do not necessarily state or reflect those of the United States Government or any agency thereof.

Available to the public from the National Technical Information Service, U.S. Department of Commerce, 5285 Port Royal Road, Springfield, VA 22161; phone orders accepted at (703) 487-465.0. 


\title{
AFBC Co-Firing of Coal and Hospital Waste
}

\author{
Quarterly Report \\ August - October 1995
}

James M. Stuart

Work Performed Under Contract No.: DE-FG21-91MC27205

For

U.S. Department of Energy

Office of Fossil Energy

Morgantown Energy Technology Center

P.O. Box 880

Morgantown, West Virginia 26507-0880

By

Donlee Technologies, Incorporated

693 North Hills Road

York, Pennsylvania 17402 


\section{TABLE OF CONTENTS}

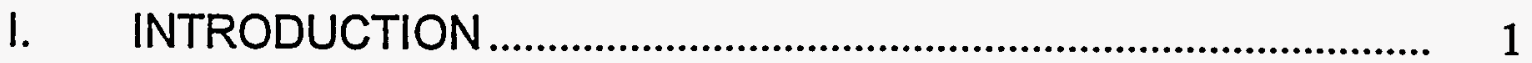

A. Project Objective....................................................................... 1

B. Reporting Period....................................................................... 1

C. Report Layout ...................................................................... 1

II. TASK ONE - Design, Specify, Procure, Install and Start-Up Facility

A. Subtask 1-A Design..................................................................... 1

B. Subtask 1-B Equipment Purchase and Fabrication....................... 2

C. Subtask 1-C Installation ............................................................ 2

D. Subtask 1-D Shredder System Verification................................ 10

E. Subtask 1E Start-Up................................................................. 11

III. TASK TWO - Obtain Permits ..................................................... 11

IV. TASK THREE - Procure Coal, Limestone and Ash Disposal Contracts ...................................... 12

V. TASK FOUR - Conduct One Year Test Program .......................... 12

VI. TASK FIVE - Prepare Final Report........................................... 13

VII. PROJECT COSTS ........................................................................ 13

VIII. SUMMARY ........................................................................... 16 


\section{LIST OF TABLES}

Page

Table 1. Lebanon VA Project Equipment Status Report............................. 3

Table 2. LVA Progress Summary Report .................................................... 7

Table 3. Task 01 - Piping Summary Progress Report ................................. 7

Table 4. Task 02 - Platforms Summary Progress Report ............................. 8

Table 5. Task 03 - Building/Control Room Summary Progress Report....... 8

Table 6. Task 04 - Equipment Summary Progress Report ......................... 9

Table 7. Task 05 - Electrical Summary Progress Report............................. . 9

Table 8. Task 06 - Building Summary Progress Report.............................. 10

Table 9. Lebanon VA Project Cost-to-Date Reported by Task ................... 18

Table 10. Lebanon VA Project Equipment Costs ......................................... 19

Table 11. Lebanon VA Project Schedule .............................................. 27 


\section{INTRODUCTION}

\section{A. PROJECT OBJECTIVE}

The project objective is to design, construct, install, provide operator training and start-up a circulating fluidized bed combustion system at the Lebanon Pennsylvania Veteran's Affairs Medical Center. This unit will co-fire coal and hospital waste providing lower cost steam for heating and possibly cooling (absorption chiller) and operation of a steam turbine-generator for limited power generation. This would permit full capacity operation of the FBC year round in spite of the VA laundry that was shut down as well as efficient destruction of both general and infectious hospital waste and steam generation. The steam generated is as follows:

- Steam $=20,000 \mathrm{lb} / \mathrm{hr}$

- Temperature $=353 \mathrm{~F}$ (saturated)

- Pressure $=125$ psig

- Steam quality $=\sim 98.5 \%$

\section{B. REPORTING PERIOD}

The reporting period is from August 1, 1995 to October 31, 1995.

\section{REPORT LAYOUT}

The Progress Reports will show progress and direction for each task and subtask. The Final Technical Report will also provide a coherent chronology of tasks and subtasks throughout the project. Weekly status meetings were held. In part, this report summarizes the primary issues discussed in those meetings and relating to the completion of this project.

\section{TASK ONE - Design, Specify, Procure, Install and Start-Up Facility}

\section{A. SUBTASK 1-A - DESIGN}

Progress: The process of filling out fact sheets for each piece of equipment for the operation and maintenance manual continues, and about $85 \%$ of the fact sheets have been completed.

The status of the fact sheets is as follows:

- 56 fact sheets have been written.

- 56 fact sheets have been typed and completed.

- 6-10 fact sheets remain to be written.

Currently, the stack, base and anchoring system have been designed and materials have been procured. The stack fabrication has not been started yet but the completion date for DONLEE fabrication and transport to the site is projected to be December 11, 1995. Installation will be 
during that week. Three other systems need to be designed by DONLEE and/or installed at the LVA site:

- Steam silencer and support - to be located next to the Southeast corner of the baghouse.

- Ash conditioner system - supports for the ash screw and the rotary valve and ash conditioner.

- Support to raise the skiphoist approximately two feet above the existing foundation floor. Note this will be done to match the two-foot raised platform to be installed by the building contractor.

The feedwater and chemical treatment system was redesigned for the new system. A vendor was selected for the chemical treatment and the pump and tank were selected. The sterilization system has been designed. Procurement of the remaining equipment will be done shortly.

The shredder system's piping and hose connections have been designed. Bids will currently be sought for the installation of these items.

\section{Problems: None}

Plans: Continue filling out fact sheets for the equipment. Continue design and drafting work.

\section{B. SUBTASK 1-B - EQUIPMENT PURCHASE AND FABRICATION}

Progress: The status of the major pieces of equipment in the procurement process is shown on Table 1. The fabrication procedure developed for the combustor, boiler, economizer and bins allowed these items to be fabricated by DONLEE.

Problems: None

Plans: Continue with authorized expenditures. Proceed with the equipment fabrication.

\section{SUBTASK 1-C - INSTALLATION}

Progress: The construction work has been broken into smaller contracts. This allows us to take advantage of smaller constructors who specialize in specific portions of the construction package. The progress in the various work being done on-site is discussed below. Table 2 lists the general tasks, their descriptions, the hours completed and percentage completion during the time of this quarter. Tables 3 through 8 shows a further breakdown of the task items during August 1 through October 31, 1995. 


\section{TABLE 1. LEBANON VA PROJECT EQUIPMENT STATUS}

\begin{tabular}{|c|c|c|c|c|c|}
\hline $\begin{array}{l}\text { 总 } \\
\text { 离 } \\
\text { 妾 } \\
\text { 总 }\end{array}$ & EQUIPMENT & VENDOR & 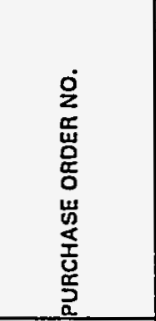 & 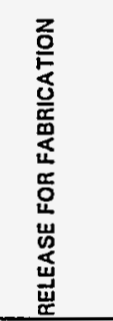 & 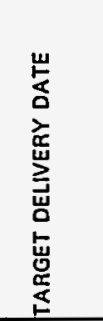 \\
\hline 1 & Arr Compressor & C.H.REED & 70054 & 531194 & $7 / 12194$ \\
\hline 2 & Ash Conditioner & DETROT STOKER & 70009 & 727793 & 1231993 \\
\hline 3 & Ash Conditioner. Chutes & DETROI STOKER & 70062 & gerses & $11 / 494$ \\
\hline 4 & Ash Handling: Storage and Scrow & MACAWBER SYSTEMS & $13456 \mathrm{~B} 70046$ & 72793 & $3 / 1494$ \\
\hline 5 & Bed Matorial Cooling/Clearing System & CSISYSTEMS INC. & 70041770042 & 512594 & $88 / 94$ \\
\hline 6 & Bin, Send (Send fumel)Replaces bed matl bin estimzted Q $\$ 10,000$ & DONLEE & wo & $5 / 1194$ & 711194 \\
\hline 7 & Bins: Ash, Umestone \& Coal & & & & \\
\hline 7a. & Conl Bins & DONLEE & wo & 5/1994 & $720 / 94$ \\
\hline $7 b$ & Umestone Bin - 30 Ton & DONLEE & wo & 5/194 & 11/1/194 \\
\hline $7 e$ & Umestone Bin-2 Ton & DONLEE & wo & $5 / 1 / 94$ & $8 / 19194$ \\
\hline $7 d$ & Ash Bins (2) & DONLEE & wo & 5/1194 & $11 / 18994$ \\
\hline 8 & Boiler \& Economizor. Boiler & DONLEE & wo & $10 / 1993$ & 429194 \\
\hline 9 & Boilor \& Economizer. Boiler Sootblower & FUEL EFFICIENCY & 70001 & $6 / 2893$ & 82293 \\
\hline 10 & Boiler \& Economizer. Boiler Sootblower-Engr Only & FUEL EFFICIENCY & 11916 & & 82293 \\
\hline 11 & Boilor \& Economizer. Economizer Casine & DONLEE & wo & $6 / 194$ & $76 / 94$ \\
\hline 12 & Boiler \& Economizer. Eeonomizer Sootblowsor & COPES-MULCAN & 419178 & 34494 & $6 / 16 / 94$ \\
\hline 13a. & Stack (Chimnoy) & TRIFABINC & 41819 & 228894 & $10 / 31 / 94$ \\
\hline $13 \mathrm{~b}$ & Stack (Chimney) - 2nd Deslon & DONLEE & wo & $2 / 10 / 95$ & $10 / 15 / 95$ \\
\hline 13e & Stack(Chimney) - Anchoring system & DONLEE/AYCoCK & 70059 & $11115 / 95$ & 12/8/95 \\
\hline 14 & Circulating Pumps, Foodwater & CHESTER PUMP & & 6/1/94 & 7115194 \\
\hline 15 & Coal Storage, Handling \& Feoding & BEAUMONT BIRCH & 134558 & 7227193 & $12215 / 93$ \\
\hline 16 & Combustor/CydionalCooling Bed Unit -No Tubes & DONLEE & wo & 6/10/93 & $111 / 93$ \\
\hline 17 & Controls Computer Package & HONEYWELL & $\$ 21908$ & $8 / 16 / 93$ & 9/1/95 \\
\hline 18 & Cooling Bed \& Economizer Tubes: & ALLEGHENY BOILER TUBE & 70000 & $6 / 15 / 93$ & 9/15/93 \\
\hline 19 & Dry hijection Fabric Filtor, Baghouse & AEROPULSE INC & 120198 & 6/3/94 & 9:19/94 \\
\hline
\end{tabular}




\section{TABLE 1. LEBANON VA PROJECT EQUIPMENT STATUS}

\begin{tabular}{|c|c|c|c|c|c|}
\hline 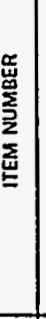 & EQUIPMENT & VENDOR & 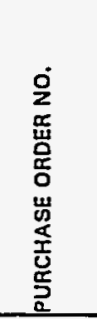 & 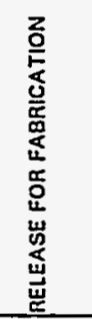 & 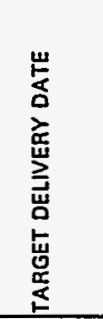 \\
\hline 20 & Ducting \& Piging & MeClure & 70035 & $9 / 28194$ & $1221 / 94$ \\
\hline 21 & Electrical Equipment \& installation & DBG/Carpenter Engr & 70024 & 23194 & 228195 \\
\hline 22 & Emissions Moritoring Equipment & ENERTEC & $14172 B$ & $8 / 293$ & $12220 / 94$ \\
\hline 23 & Emissions Morritoring Equipment Oxygen & WAGREGORY $\&$ CO & 70040 & $6 / 3194$ & $7 / 20194$ \\
\hline 24 & Expansion Joints & SENIOR FLEXONICS & 70011 & $8 / 8 / 93$ & $10 / 28193$ \\
\hline 25 & Fans \& Blowers: $A C B \& \angle C B$ *. & SPENCER TURBINE & 41809 & $3 / 15 / 94$ & $6 / 30 / 94$ \\
\hline 26 & Fans \& Blowers: Primary \& 10 & ROBINSON & 41811 & $6 / 28 / 93$ & $12331 / 93$ \\
\hline 27 & Flyash Roinjection System & DONLEE FOX VALVE & 70034 & 6,6194 & $7 / 15 / 94$ \\
\hline 28 & Flyash Reinlection System: Bed Men Blowers & R.M.ASSC & 41810 & $5 / 25 / 94$ & $720 / 94$ \\
\hline 29 & Natural Gas line moved & UG & 70028 & $3 / 1 / 94$ & $3 / 15 / 94$ \\
\hline 30 & Hospital Waste, Handling \& Sub-Systems & ESSEX CONVEYOR & 41820 & $3 / 1 / 94$ & $9 / 2394$ \\
\hline 31 & Instruments: Prossure hdicators/Transmitters & DWYERHONEYWELL & 70055 & E/15ig4 & 7115994 \\
\hline 32 & Instruments: Prossuro Transmitters & HONENWELL & 70010 & $7 / 27 / 93$ & $8 / 25 / 93$ \\
\hline 33 & Instruments: Prossure Transmitters (Additional) & HONEYWEL & 70045 & $6 / 15 / 94$ & $7 / 15 / 94$ \\
\hline 34 & Instruments: Thermocouplos & $\cos$ & 70052 & $67 / 94$ & $7 / 19194$ \\
\hline 35 & Insulation Materials a hstallation & DONLEE & wio & 771194 & 9/18/94 \\
\hline 36 & Umestone Storage, Handling \& Foeding & MACAWBER SYSTEMS & $41684 B$ & 727193 & $12 / 15 / 93$ \\
\hline 37 & Outsido Roviow of Bidg-Proliminary/Final & ENTECH & & $8 / 2493$ & $7 / 1 / 93$ \\
\hline 38 & Palinting & DONLEE & & 7/15/94 & 228996 \\
\hline 39 & Plant Encl/silio Prop/Foundation: Gootechrical Engr. & SCHNABEL & 70027 & $2 / 16194$ & $7 / 1 / 94$ \\
\hline 10 & Plant Enc//Site Prop/Foundation: Bldg \& Foundation now & ARTHUR FUNK & 70023 & 124194 & 9/30/94 \\
\hline 41 & Plamt Encl/Sito Prop/Foundation: Building & & & 9/30/93 & $4 / 29 / 94$ \\
\hline 42 & Piant Encl/Sito Prop/Foundation: Dosign & DBGistackbock & & $6 / 10 / 93$ & 2/15/94 \\
\hline 43 & Plant Encl/Sito Prop/Foundation: Engineor & DBG/Stockbsek & 70026 & $2 / 16 / 94$ & $9 / 30 / 94$ \\
\hline 44 & Plant Encl/Sito Prop/Foundation: Foundation & & & $9 / 30 / 93$ & $429 / 94$ \\
\hline
\end{tabular}




\section{TABLE 1. LEBANON VA PROJECT EQUIPMENT STATUS}

\begin{tabular}{|c|c|c|c|c|c|}
\hline 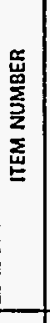 & EQUIPMENT & VENDOR & 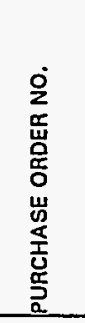 & 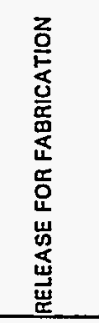 & 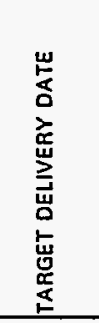 \\
\hline 45 & Plattorms, Supports and Stairs and Dosign & BSM, he. & 70084 & 927794 & 1215194 \\
\hline 46 & Refractory Materials \& installation: installation & DONLEE & wo & 1111193 & $5 / 3194$ \\
\hline 47 & Refractory Materials \& installation: Materials & J.T.THORPE & 70002 & 628193 & $8 / 30 / 94$ \\
\hline 48 & Rofifigerated Room & PERLEY-HALLADAY & 70012 & 728893 & $8 / 30194$ \\
\hline 49 & Scalo & BSM SCALE & 70048 & 6/8998 & 830194 \\
\hline 50 & Shreddor & SSI SHREDDING SYSTEMS & & & \\
\hline 51 & Shredder Blower & ROBINSON & $38764 \mathrm{~B}$ & $8 / 20193$ & $12331 / 93$ \\
\hline 52 & Shredder. Move from York to Sito & DONLEE & 70035 & $11 / 19993$ & $7115 / 94$ \\
\hline 53 & Sildo Gutes & ROVALVETECHNAFLOW & 70007 & 728193 & 228194 \\
\hline 54 & Soil Borings & Schnabel & & & \\
\hline 55 & Sturt-vo Bumer & ECLUPSEYORKARE & 70013 & 9/1993 & $13 / 94$ \\
\hline 56 & Start-up Bumer (Mod. Motor) & HONERWEU & 70014 & $8 / 20 / 93$ & 9r3093 \\
\hline 57 & Startup Bumer Panel & DONLEE & w.o. & $127 / 93$ & 630194 \\
\hline 58 & Stoam Silencer & MBRATON \& NOLSE ENGR & 70070 & 67194 & $8 / 15994$ \\
\hline 59 & Stootwork or Equipment Support & DONLEE & wo & $11 / 15 / 93$ & $5 / 30194$ \\
\hline 60 & Sterlization Systom & DONLEE & 70067 & $6 / 8994$ & $8 / 15 / 94$ \\
\hline 61 & Sterilization Testing & DONLEE & 70049 & $8 / 30 / 94$ & 930194 \\
\hline 62 & Iransformer for Lob VA Equipment & Biatt 8 movers & 70085 & 731968 & 121198 \\
\hline 63 & Values \& Dampors & IPS & 70044 & $5 / 31984$ & 726194 \\
\hline 64 & Vendor Equipment Installation & AYCOCK & 70059 & & $12 / 15 / 94$ \\
\hline 65 & Computerized Portablo Analyzers & ECOMAmerica & 70030 & $3 / 11194$ & $3 / 25 / 94$ \\
\hline 66 & Additonal payment porrormanco bonds & $T B D$ & & & \\
\hline 67 & Onsite reffractory cure & Hotworks & 70081 & $10 \pi / 94$ & 1/15/96 \\
\hline 68 & Bonding and Grounding & TBO & & & \\
\hline & Sump pumps and controls & Rasdon & & & \\
\hline
\end{tabular}


CONTRACT DE-FC21-91MC27205

Quarterly Progress Report

(August 1, 1995 - October 31, 1995)

Page 6

TABLE 1. LEBANON VA PROJECT EQUIPMENT STATUS

\begin{tabular}{|c|c|c|c|c|c|}
\hline 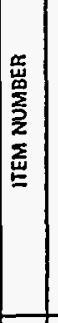 & EQUIPMENT & VENDOR & 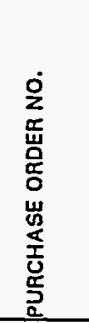 & 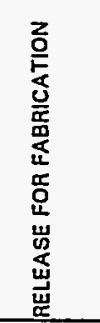 & 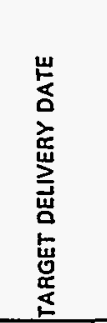 \\
\hline 70 & Steam/Faadwator Vatives & IPS & 70092 & & \\
\hline 71. & Shredder Hydraulic Fillor & ss! & 70094 & $1 / 2495$ & $2 / 15 / 95$ \\
\hline 72 & Air Camons & Airmatics & 70099 & 16/95 & $1 / 20 / 95$ \\
\hline 73 & Nolso Supprossion: Motor/Blowers & BRD Noisomibration & 70096 & $11 / 29994$ & 12220194 \\
\hline 74 & Heatless Ar Dryer & Air Fow Co., he. & 70191 & $125 / 95$ & $3 / 10 / 95$ \\
\hline 75 & Orifices and venturis & CIBI NES & 70093 & 11/4955 & $2 / 15 / 95$ \\
\hline 76 & Cant for medical wasto & CONSOLDATED PLASTC CO & 70102 & 125595 & $2 / 1 / 95$ \\
\hline 77 & Silte trailer rental - 13 months & GE CAPTIAL MODULAR SPACE & 70098 & 1220194 & $1 / 23 / 95$ \\
\hline 78 & & DONLEE & & $9 / 1 / 95$ & $11 / 30995$ \\
\hline 79 & Added Wghting & DONLEE & & 9/1995 & 1130195 \\
\hline 80 & Sump Pump/Controls & RAEDEN & & 9/1995 & $10 / 30 / 95$ \\
\hline 81 & Cal Gases and Requaliors & SCOTT SPECLALTY & & 9/1/95 & 12/15/95 \\
\hline 82 & SinklShower Deconoamination Stations & LAB SAFETY & & 9/1995 & 128895 \\
\hline 83 & Sand for Bods & U.S.SILCA SAND & 70080 & 9/15/95 & $12 / 15 / 95$ \\
\hline 84 & Coal Pit Cover & DONLEE & & $9 / 15 / 95$ & $11 / 15 / 95$ \\
\hline 85 & Grizzly Cover & DONLEE & & 9/15/95 & $12 / 15 / 95$ \\
\hline & Chemical Foedunater System & INutmeg & 70112 & $10 / 31 / 95$ & $12 / 15 / 95$ \\
\hline
\end{tabular}




\begin{tabular}{|c|l|r|r|r|c|}
\hline \multicolumn{7}{|c|}{ Table 2. LVA PROJECT PROGRESS SUMMARY REPORT } & $\ddots$ \\
August 1, 1995 -October 31, 1995 & $\begin{array}{c}\text { Pctual } \\
\text { Aercentage } \\
\text { Task }\end{array}$ & \multicolumn{1}{|c|}{ Description } & $\begin{array}{c}\text { Estimated } \\
\text { Man-Hours } \\
\text { to Complete }\end{array}$ & $\begin{array}{c}\text { Percentage } \\
\text { Man-Hours } \\
\text { Completed } \\
\text { Oct. 31, 1995 }\end{array}$ \\
\hline 01 & Piping & 1800 & 1152 & 65 & 88 \\
\hline 02 & Platform Installation & 880 & 937 & 25 & 100 \\
\hline 03 & Control Room & 300 & 265 & 50 & 90 \\
\hline 04 & Equipment Installation & 1420 & 917 & 75 & 88 \\
\hline 05 & Electrical & 2200 & 1180 & 40 & 75 \\
\hline 06 & Building & 400 & 100 & 90 & 92 \\
\hline 07 & Insulation & 600 & 0 & 0 & 0 \\
\hline 08 & Painting & 300 & 0 & 0 & 0 \\
\hline & TOTAL & 7900 & 4551 & 60 & 82 \\
\hline
\end{tabular}

\begin{tabular}{|l|l|r|}
\hline \multicolumn{1}{|c|}{ TABLE:3 TASK 01-PIPING } \\
\hline \multicolumn{1}{|c|}{$\because \quad$ Work Description } & \% Complete \\
\hline Subtask & \multicolumn{1}{|c|}{ Summary Progress Report - Complete } \\
\hline $1-01$ & Compressed air system & 100 \\
\hline $1-02$ & Water service system & 96 \\
\hline $1-03$ & Natural gas lines & 100 \\
\hline $1-04$ & Steam piping & 85 \\
\hline $1-05$ & Feed recirculation water & 95 \\
\hline $1-06$ & Ash silo piping & 90 \\
\hline $1-07$ & Solids lines & 70 \\
\hline $1-08$ & Air duct & 95 \\
\hline $1-09$ & Fuel and gas duct & 95 \\
\hline $1-10$ & Sterilization & 0 \\
\hline $1-11$ & Hospital waste & 75 \\
\hline $1-12$ & Instrumentation & 40 \\
\hline $1-13$ & Sample lines & 0 \\
\hline $1-14$ & Baghouse rework & 100 \\
\hline $1-15$ & Punch list & 10 \\
\hline
\end{tabular}


CONTRACT DE-FC21-91MC27205

Quarterly Progress Report

(August 1, 1995 - October 31, 1995)

Page 8

\begin{tabular}{|l|l|r|}
\hline \multicolumn{1}{|c|}{ TABLE 4-TASK 02-PLATFORMS } & \multicolumn{1}{|c|}{ Summary Progress Repoit- 100\% Complete } \\
\hline Subtask & \multicolumn{1}{|c|}{ Work Description } & \% Complete \\
\hline $2-01$ & Small pit & 100 \\
\hline $2-02$ & Combustor & 100 \\
\hline $2-03$ & Hot cyclone & 100 \\
\hline $2-04$ & Sluice bed & 100 \\
\hline $2-05$ & Heat exchanger & 100 \\
\hline $2-06$ & Startup burner & 100 \\
\hline $2-07$ & Shredder & 100 \\
\hline $2-08$ & Coal silo & 100 \\
\hline $2-09$ & Boiler \& economizer & 100 \\
\hline $2-10$ & Ash silo & 100 \\
\hline $2-11$ & Large pit & 100 \\
\hline $2-12$ & Final punch list & 100 \\
\hline $2-13$ & Additional platforms & 63 \\
\hline
\end{tabular}

\begin{tabular}{|l|l|r|}
\hline \multicolumn{3}{|c|}{ TABLE 5. TASK 03 - BUILDINGIFOUNDATION - CONTROL ROOM : } \\
Summary Progress Report - 90\% Complete
\end{tabular}




\begin{tabular}{|l|l|r|}
\hline \multicolumn{2}{|c|}{ Summary Progress Report-88\% Complete } \\
\hline \multicolumn{1}{|c|}{ Work Description } \\
\hline Subtask & \multicolumn{1}{|c|}{ W } & Complete \\
\hline $4-01$ & Dryer & 100 \\
\hline $4-02$ & Refrigeration system & 100 \\
\hline $4-03$ & Stack fabrication & 50 \\
\hline $4-04$ & Stack erection & 0 \\
\hline $4-05$ & Sterilization skid & 95 \\
\hline $4-06$ & Ash conditioning system & 0 \\
\hline $4-07$ & Baghouse rework & 100 \\
\hline $4-08$ & Steam silencer & 0 \\
\hline $4-09$ & Skiphoist rework & 80 \\
\hline $4-10$ & Limestone storage bin & 100 \\
\hline $4-11$ & Weigh belt rework & 80 \\
\hline $4-12$ & Coal silo rework & 94 \\
\hline $4-13$ & Hot cyclone & 97 \\
\hline $4-14$ & Ash silo system & 100 \\
\hline $4-15$ & Combustor & 96 \\
\hline
\end{tabular}

\begin{tabular}{|l|l|r|}
\hline \multicolumn{2}{|c|}{ TABLE 7. TASK 05 - ELECTRICAL } \\
\multicolumn{1}{|c|}{ Summary Progress Report - 75\% Complete } \\
\hline Subtask & \multicolumn{1}{|c|}{ Work Description } & \% Complete \\
\hline $5-01$ & Motor control center & 85 \\
\hline $5-02$ & Dust suppression & 100 \\
\hline $5-03$ & Startup burner & 95 \\
\hline $5-04$ & Sootblower & 75 \\
\hline $5-05$ & Fans control & 75 \\
\hline $5-06$ & Bed cleaning system & 60 \\
\hline $5-07$ & Limestone and ash & 20 \\
\hline $5-08$ & Baghouse & 80 \\
\hline $5-09$ & Local thermocouple & 80 \\
\hline $5-10$ & Coal handling system & 85 \\
\hline $5-11$ & Hospital waste sterilization & 40 \\
\hline $5-12$ & Building light & 55 \\
\hline $5-13$ & Main controls and analyzers & 39 \\
\hline $5-14$ & Boiler & 0 \\
\hline
\end{tabular}




\begin{tabular}{|l|l|r|}
\hline \multicolumn{2}{|c|}{ TABLE 8. TASK 06-BUILDING } & \multicolumn{1}{|c|}{ Summary Progress Report-92\% Complete } \\
\hline \multicolumn{1}{|c|}{ Work Description } & \% Complete \\
\hline Subtask & \multicolumn{1}{|c|}{ W } & 0 \\
\hline $6-01$ & Roof opening - Will be performed when the stack is installed. & 100 \\
\hline $6-02$ & Drywall ceiling & 100 \\
\hline $6-03$ & Ventilation system & 0 \\
\hline $6-04$ & Loading dock platform & 0 \\
\hline $6-05$ & Paving & 0 \\
\hline $6-06$ & Seeding & \\
\hline
\end{tabular}

TASK 07 - INSULATION - Summary Progress Report. The insulation work has not started yet. A vendor will be selected shortly.

TASK 08 - PAINTING - Summary Progress Report. The outside painting and the interior structural painting have not started yet. A vendor needs to be selected.

Problems: The electrical contractor came to the site much later than the other contractors and has been behind schedule through this quarter due to providing insufficient manpower for much of this time.

Plans: The installation continued this quarter and is projected to be completed by late December.

\section{SUBTASK 1-D - SHREDDER SYSTEM VERIFICATION AND TESTING}

Part of Phase I Contract testing to be done at DONLEE Pilot facility.

Progress: Task completed in June 1992.

Problems: None.

Plans: Task completed in June 1992. Sterilization testing will be completed prior to completion of the installation. This testing uses a full-scale mock-up of a portion of the shredder hopper. The testing nozzles used are those to be used in the actual shredder system to ensure proper design. 
CONTRACT DE-FC21-91MC27205

Quarterly Progress Report

(August 1, 1995 - October 31, 1995)

Page 11

\section{E. SUBTASK 1-E - START-UP}

Progress: Shakedown, startup and operation will begin after the completion of the equipment and instrument installation. The various subsystems of the facility will be started up one at a time during pre-startup check out. The 14 subsystems are:

1. Compressed air

2. Gas lines and startup burner

3. Water service lines

4. Baghouse

5. Limestone system

6. Coal handling system

7. Combustor and hot cyclone

8. Ash reinjection

9. Boiler and steam lines and feed and recirculation water lines

10. Ash conditioning system

11. Hospital waste

12. Main control system

13. Analyzers

14. Stack

Subsystems 1 through 9 are currently near, or above $90 \%$ complete and can be checked out as needed.

A computerized preventive maintenance program will be developed during shakedown, startup and the test program.

Problems: The Lebanon VA is currently searching for a responsible individual who will repair, replace or maintain the Honeywell control system of the CFB facility.

Plans: The facility is anticipated to be completed during the winter of 1995 . Work has begun on the Training Program and the Operation and Maintenance Manual.

\section{TASK TWO - Obtain Permits}

Progress: Application for the extension of the Plan Approval to November 30, 1995 for the Lebanon VA facility was sent to the PA DEP. DONLEE has recerved the Plan Approval and the 180 day extension. This time period is now running out. 
Problems: None. Preparation for the PA DEP site review after construction has started since the installation of the equipment has begun.

Plans: Since the construction is not yet complete, the Plan Approval will be extended again in early November so that construction and installation can be completed. This situation is due to the 5-month delay of the approval of the additional funds.

\section{TASK THREE - Procure Coal, Limestone and Ash Disposal Contracts}

Progress: Early in the project the coal, limestone and ash disposal contracts could not be finalized because the initial supply date was in question due to NEPA approval related delays. Lebanon VA had received a supply proposal from Naughton Energy for coal, limestone and for ash disposal. During May 1994 the Lebanon VA set up a contract for procuring coal and limestone and for disposing of the generated ash when the facility is operational.

Problems: Naughton has a three-year contract (through September 1997) to supply the coal and limestone, and to dispose of the ash generated. The contract started in October 1994. From then until the time that the facility is operational, the right to purchase the coal and limestone and to dispose of ash is lost.

Plans: Limestone and coal shipments will be obtained to do check outs of the coal and limestone systems.

\section{TASK FOUR - Conduct One Year Test Program}

Progress: This task will be performed after the installation, pre-startup check outs and startup/shakedown of the facility have been completed. Stack testing and biospore testing are required by the Pennsylvania Department of Environmental Protection to demonstrate performance and for the proof of DRE (destruction removal efficiency), respectively. At least one test of each type are required by PA DEP, however, more tests can be required. Due to funding limitations, only one or two stack tests or biospore tests can be performed. A test matrix will also be performed to demonstrate the performance and operation limitations of the CFB facility and its emission levels.

\section{Problems: None.}

Plans: A preliminary request for proposal for performing stack sampling and biospore tests have been written and sent to four (4) vendors for competitive bids on October 13, 1995. These proposals will be reviewed for cost and content. A stack sampling vendor will be selected 
and the final costs of the tests will be determined. The stack sampling vendor will also update and develop the protocol for the test facility.

\section{TASK FIVE - Prepare Final Report}

Progress: None. The report is due 3 months after the test program is completed.

Problems: None. The task is to be completed after the test program is finished.

Plans: Currently information has been gathered concerning the equipment and facility. Preparation is being made to perform a matrix of tests that will demonstrate the performance and operation limits of the CFB system, quantify emission levels, identify problem areas and aid in performing scale-up analyses for future commercial designs.

\section{PROJECT COSTS}

\section{Changes to the contract}

The following items have undergone price increases during this project. (The numbers in parentheses refer to Table 10 item numbers.)

- An air compressor will need to be purchased for the new facility. It was originally believed that the present system would be able to provide sufficient air quantities but the new facilities requirements are larger than originally anticipated. The cost of a $300 \mathrm{cfm}$ air compressor rated at $110 \mathrm{psi}$ was $\$ 21,015$ (revised). The air is supplied for the pneumatic transport of limestone and ash, pneumatic slidegates and instrumentation. (1)

- An ash conditioner needed to be added to the contract. The Solid Waste Division of Pennsylvania's Department of Environmental Resources requires that the ash be conditioned with water before transport. The ash conditioner was supplied at a cost of $\$ 59,804$ (revised), including ducts and screw conveyors. $(2,3,4)$

- The cost of the ash handling storage and screw system has increased to $\$ 151,941$ due to purchasing $21 \mathrm{NiHard} 45^{\circ}$ elbows for pneumatic ash transport. (4)

- The bed cleaning system which processes the ash generated from the combustion of the coal; limestone and medical waste currently costs $\$ 26,114$. The vendor agreed to upgrade the equipment being supplied to meet the equipment specifications. (5)

- The scope of the sand silo design has been reduced to a sand "funnel," resulting in a cost reduction of $\$ 5,000$ to $\$ 10,000$. The cost of the sand funnel was $\$ 2925$. (6) 
- The total cost of the bins: ash, limestone (2) and coal has increased from $\$ 43,065$ to an estimated \$123,663. (7a thru 7d).

- The boiler required $\$ 8,111.00$ of additions to meet the VA specifications. This number will be revised pending final boiler design. (8)

- The cost of the economizer sootblower was $\$ 8,784$. (12)

- The redesign of the stack is complete. The total cost of the stack is now $\$ 69,428$. (13)

- The feedwater circulating pump was bought by LVAMC. DONLEE's cost is zero. (14)

- The coal feeders were originally proposed to be screws. The VA has requested weighing capability. Weigh belt feeders were selected in place of screw feeders. The cost was $\$ 45,690.00$. (15)

- The annunciator panel requested by the VA will be approximately $\$ 8160.00$. (17)

- The cost of the controls computer package has increased from $\$ 83,442$ to $\$ 97,001$. This cost increase is due to a required increase in the $1 / O$ capacity of the control system and for two computer courses. (17)

- The baghouse and sorbent injection system currently cost $\$ 138,523$ (revised). (19)

- The cost of the vendor doing the ducting and piping has increased to $\$ 249,495$ (revised). (20)

- The electrical contractor cost for the facility installation is currently $\$ 279,348$ (revised). (21)

- The emissions monitoring system required $\$ 56,500$ above the proposal for the $\mathrm{HCl}$ monitoring system and heated sample lines. (22)

- An oxygen analyzer to be used to measure oxygen at the boiler entrance and to be used to help control oxygen levels in the system was needed at a cost of $\$ 6429$. (23)

- Expansion joints were needed to allow for thermal growth throughout the system at a cost of $\$ 25,862$. (24)

- The cooling bed and lift channel blowers cost $\$ 13,060$. (25)

- The cost to move the gas lines at the facility was originally $\$ 5,500$. This cost was deleted by the gas company, UGI, in early February. (29)

- The hospital waste handling and subsystems (or skip hoist) currently cost $\$ 36,815$. (30)

- The cost of the added transmitters for pressure and flow indication added to the specification, was $\$ 4,097$. This cost increase is due to the number of transmitters that have been added. (33)

- The painting currently costs $\$ 12,240$ (revised). (38). 
- Geotechnical Engineering Services for the building and foundation have been added to ensure that the facility is constructed properly and safely. The cost is partly offset by the October 1993 budget cost of the building and foundation. The cost of the services was $\$ 9,512$. (39)

- The building and foundation cost is currently $\$ 636,628$ due to change order increases. (40).

- Design Engineering Services have been added to provide independent supervision for the construction. The cost of these services is included in the October 1993 budget cost of the building and foundation. The cost has since been reduced to $\$ 10,911$ from $\$ 17,000$.

- The cost of the design and manufacture of the initial platforms, supports and ladders was $\$ 27,000$. (45)

- The refractory engineering, materials and installation vendor's cost was $\$ 88,007$. (47)

- A refrigerated room is required for the storage of medical waste in the event that the unit is not operating. The cost of the refrigerated room was $\$ 15,407$ with freight included. (48)

- The Solid Waste Division of Pennsylvania's Department of Environmental Resources requires that the medical waste be weighed before disposal. The cost of a scale to be mounted in the loading dock was $\$ 4382$. (49)

- The price of the shredder blower has increased due to a freight charge. The final price was $\$ 3,140$. (51)

- Slidegates were needed for the coal, limestone and ash handling systems at a cost of $\$ 52,665$. (53)

- Soil borings were required to determine soil bearing capacity before the foundation design could be started. It was originally believed that the VA had this information. The cost of the soil borings was $\$ 5850$. (54)

- The start-up burner system, including its panel and motors, for the circulating fluidized bed cost is $\$ 10,792$. $(55,56,57)$

- The cost of the steelwork or equipment support (structure) has increased from $\$ 72,290$ to $\$ 143,639$ (estimated). (59)

- The general valves for the circulating fluidized bed system currently cost $\$ 26,065$. (63)

- The cost of the vendor equipment installation, including the platform installation and extras, is now $\$ 478,107$ (revised). (64)

- The cost of additional payment/performance bonds has been maintained in the individual contracts (vendor equipment installation and ducting and piping). This item as a result is $\$ 0$. (66)

- The additional feedwater and steam valves were ordered at a cost of $\$ 2,258$ (revised). (70)

- Spare shredder hydraulic filters were purchased for $\$ 421$. (71) 
CONTRACT DE-FC21-91MC27205

Quarterly Progress Report

(August 1, 1995 - October 31, 1995)

Page 16

- The air cannons were purchased for the coal silos at a cost of $\$ 5,527$. (72)

- The noise control pads and bases for the blowers, fans, compressor and shedder hydraulic unit have been purchased and installed at a cost of $\$ 4,288$. (73)

- A heatless air dryer was purchased to provide air dried to $-40 \mathrm{~F}$ dewpoint, at a cost of $\$ 7,028$ (revised). (74)

- The orifices and venturis for flow measurement have been designed and cost $\$ 12,932$. (75)

- A cart for medical waste handling was purchased to check out the skip hoist and shredder equipment. The cart cost was $\$ 682$. However, this cart was returned when it was discovered that the cart design had changed, and the cart dimensions were too large to be used. Another cart design was chosen by DONLEE and LVA and six or more have been purchased by LVA. (76)

- The site trailer for an office and storage space was rented for a minimum of 4 months at a cost of $\$ 2,624$ for an expected 13 months. (77)

- The equipment for the chemical feedwater system has been costed at $\$ 1,305$. (78)

Contract Costs-to-Date:

The Lebanon VA Project Costs-to-Date are shown on Table 9.

\section{Equipment Costs}

The equipment costs are shown on Table 10 Lebanon VA Project Equipment Cost Summary. Several of these costs are preliminary and purchase orders have not been released yet.

\section{SUMMARY}

The State permitting process required for construction will be completed in early November to allow installation and construction to be completed. Operating permits will be obtained after construction has been completed. A request for proposal for stack sampling and biospore tests was released to four (4) vendors in mid-October. The proposals shall be reviewed during November and the stack sampler will be selected.

Funding was approved as of August 1, 1995. Construction and installation resumed on August 21, 1995 at the LVAMC. Construction and installation continues and will be completed by late December 1995. 
Fabrication of the stack parts and transport of these items to the site will be done by December 11,1995 . The steam silencer support system, the ash conditioning system supports and the skiphoist must all be designed and installed.

Pre-startup check outs of the subsystems will start in November.

A current schedule for the project is included with this report. 
Table 9. Lebanon VA Project Costs-to-Date Reported by Task

\begin{tabular}{|c|c|c|c|c|c|c|c|c|c|}
\hline \multirow[b]{2}{*}{ TASK } & \multicolumn{3}{|c|}{ ACTUAL } & \multirow{2}{*}{$\begin{array}{l}\text { May-95 } \\
\text { Jul-95 } \\
\text { QRTLY } \\
\text { TOTAL } \\
\end{array}$} & \multicolumn{3}{|c|}{ ACTUAL } & \multirow{2}{*}{$\begin{array}{l}\text { Aug-96 } \\
\text { Oct-95 } \\
\text { QRTLY } \\
\text { TOTAL } \\
\end{array}$} & \multirow{2}{*}{$\begin{array}{c}\text { TO-DATE } \\
\text { CONTRACT } \\
\text { COSTS } \\
\end{array}$} \\
\hline & $\begin{array}{c}48 \\
\text { May-95 } \\
\end{array}$ & $\begin{array}{c}49 \\
\text { Jun-25 } \\
\end{array}$ & $\begin{array}{c}50 \\
\text { Jul-95 } \\
\end{array}$ & & $\begin{array}{c}32 \\
\text { Aug-95 } \\
\end{array}$ & $\begin{array}{c}33 \\
\text { Sep-96 }\end{array}$ & $\begin{array}{c}34 \\
\text { Oct-95 } \\
\end{array}$ & & \\
\hline TASK I: DESIGN/BUILD/INSTALL & $18,814.75$ & $33,652,01$ & $262,124.61$ & $314,591.37$ & $77,225.00$ & $122,485.51$ & $128,496.01$ & $328,206.52$ & $\$ 5,854,883.97$ \\
\hline TASK II: PERMITTING & & & & & & & & & $\$ 38,030.59$ \\
\hline $\begin{array}{c}\text { TASK III: OBTAIN COAL, LIMESTONE } \\
\text { \& ASH CONTRACTS } \\
\end{array}$ & & & & & & & & & $\$ 44,098.29$ \\
\hline TASK IV: TESTING & & & & & & & & & \\
\hline TASK V: FINAL REPORT & & & & & & & & & \\
\hline PROJECT TOTAL & $18,874.15$ & $33,691.61$ & $262,124.61$ & $314,690,37$ & $77,225.00$ & $122,869.63$ & $128,496.01$ & $328,590.64$ & $\$ 6,253,451,70$ \\
\hline COST SHARE & (68.37) & 64.29 & $21,757.74$ & $21,753.66$ & $2,417.15$ & $7,335.24$ & $7,885.89$ & $17,638.28$ & $\$ 412,373.89$ \\
\hline DOE BILLING & 18,94252 & $33,627.32$ & $240,366.87$ & $292,936.71$ & $74,807.85$ & $115,534.39$ & $120,610.12$ & $310,952.36$ & $\$ 5,841,077.81$ \\
\hline
\end{tabular}


Table 10. Lebanon VA Project Equipment Costs

\begin{tabular}{|c|c|c|c|c|c|c|c|c|c|}
\hline 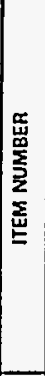 & EQUIPMENT & VENDOR & 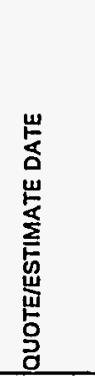 & 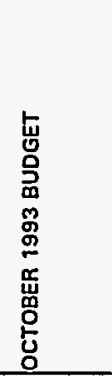 & 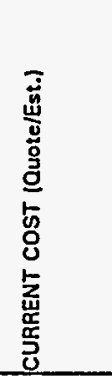 & 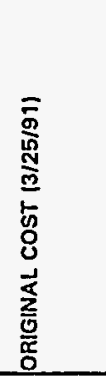 & 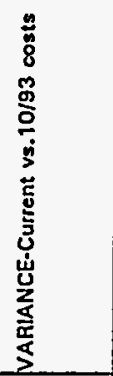 & 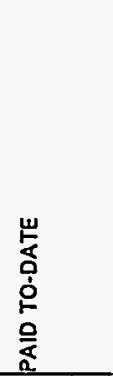 & 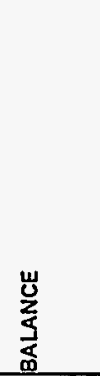 \\
\hline 1 & Ar Compressor & C.H. REED & $6 / 1 / 93$ & $\$ 21,801$ & $\$ 21,015$ & & (\$786) & $\$ 21,015$ & so \\
\hline 2 & Ash Conditionor & DETROIT STOKER & $7 / 22 / 93$ & $\$ 34,815$ & $\$ 34,815$ & & so & $\$ 34,815$ & so \\
\hline 3 & Ash Condiboner: Chutos & DETROIT STOKER & $5 / 28 / 93$ & $\$ 1,000$ & $\$ 2,979$ & $\$ 0$ & $(\$ 1,021)$ & $\$ 2,979$ & so \\
\hline 1 & Ash Handling: Storage and Scrow & MACAWBER SYSTEMS & $8 / 10 / 93$ & $\$ 123,985$ & $\$ 151,941$ & $\$ 83,200$ & $\$ 27,956$ & $\$ 145,995$ & $\$ 5,946$ \\
\hline 5 & Bod Matorlal Cooling/Cloaning Systom & CSISYSTEMS INC. & $9 / 2 / 93$ & $\$ 21,113$ & $\$ 26,114$ & $\$ 31,200$ & $\$ 5,001$ & 226,111 & so \\
\hline 6 & Bin, Sand (Sand funnol)-Roplacos bod marl bin os tumatod $Q \$ 10,000$ & DONLEE & & so & $\$ 2,925$ & $\$ 0$ & $\$ 2,925$ & $\$ 2,925$ & so \\
\hline 7 & Bins:Ash, Umostono \& Coal & & & so & & & & so & \\
\hline $7 a$ & Conl Bins & DONLEE & & $\$ 18,948$ & $\$ 55,805$ & & $\$ 36,857$ & $\$ 55,805$ & so \\
\hline $7 b$ & Umesione Bin-30 Ton & DONLEE & & $\$ 6,160$ & $\$ 11,108$ & & $\$ \mathbf{5 , 9 4 8}$ & $\$ 14,408$ & so \\
\hline $7 c$ & Úmostono Bin -2 Ton & DONLEE & & $\$ 2,584$ & $\$ 4,200$ & & $\$ 1,616$ & $\$ 4,200$ & $\$ 0$ \\
\hline $7 d$ & Ash Bins (2) & DONLEE & & $\$ 15,073$ & $\$ 34,250$ & & $\$ 19,177$ & $\$ 34,250$ & so \\
\hline 8 & Boiler \& Economlzer: Bollor & DONIEE & $5 / 15 / 93$ & $\$ 11,178$ & $\$ 41,478$ & $\$ 58,050$ & so & $\$ 11,178$ & so \\
\hline 9 & Boller \& Economizer: Boller Sootblower & FUEL EFFICIENCY & $6 / 18 / 93$ & $\$ 5,102$ & $\$ 5,113$ & $s 0$ & $\$ 11$ & $\$ 5,113$ & so \\
\hline 10 & Boller \& Economizer: Bollor Sootblowor-Engr Only & FUEL EFFICIENCY & $6 / 18 / 93$ & $\$ 1,300$ & $\$ 1,300$ & & $\$ 0$ & $\$ 1,300$ & so \\
\hline
\end{tabular}


AFBC Co-Fiving of Coal and Hospital Waste CONTRACT DE-FC21-91MC27205

Quarterly Progress Report

(August 1, 1995 - October 31, 1995)

Page 20

Table 10. Lebanon VA Project Equipment Costs

\begin{tabular}{|c|c|c|c|c|c|c|c|c|c|}
\hline 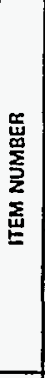 & EQUIPMENT & VENDOR & 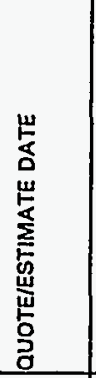 & 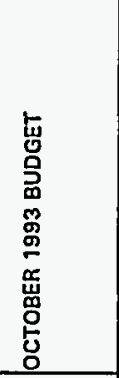 & 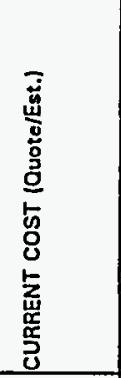 & 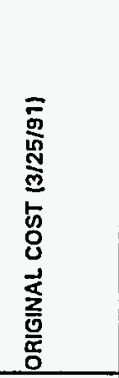 & 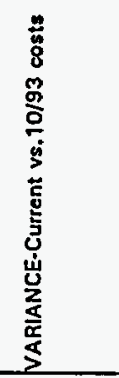 & 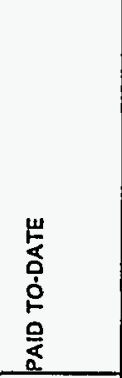 & 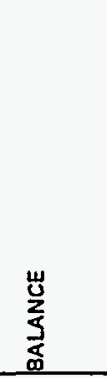 \\
\hline 11 & Bollor 8 Economlzar: Economlzor Casing & DONLEE & $5 / 15 / 93$ & $\$ 6,352$ & $\$ 8,205$ & & $\$ 1,853$ & $\$ 8,205$ & so \\
\hline 12 & Boller 8 Economizer: Economizer Soolblower & COPES.VULCAN & 6/9/93 & $\$ 7,923$ & $\$ 8,784$ & & $\$ 861$ & $\$ 8,781$ & so \\
\hline 132 & Stack (Chimnov) & TRI FAB INC & $8 / 3 / 93$ & $\$ 21,921$ & $\$ 19,128$ & $\$ 9,390$ & $(52,493)$ & $\$ 19,428$ & s. \\
\hline $13 \mathrm{~b}$ & Stack (Chimnoy) - 2nd Dosign & DONLEE & $27 / 95$ & $\$ 0$ & $\$ 25,000$ & $\$ 0$ & $\$ 25,000$ & 57,045 & $\$ 17,955$ \\
\hline $13 \mathrm{c}$ & Stuck (Chimnoy) - Archoring systom & DONLEEIAYCOCK & $8 / 7195$ & $\$ 0$ & $\$ 25,000$ & $\$ 0$ & $\$ 25,000$ & $\$ 5,517$ & $\$ 19,483$ \\
\hline 14 & Clrculating Pumps, Foodwaler & CHESTER PUMP & $7 / 15193$ & $\$ 7,000$ & $\$ 0$ & $\$ 9,640$ & $(57,000)$ & $\$ 0$ & $\$ 0$ \\
\hline 15 & Coal Storage, Hendling \& Foeding & BEAUMONT BIRCH & $7 / 21 / 93$ & $\$ 291,152$ & $\$ 297,203$ & $\$ 265,200$ & $\$ 6,051$ & $\$ 297,203$ & so \\
\hline 16 & CombustorlCyclonelCoollon Bod Unit -No Tubos & DONLEE. & $5 / 15 / 93$ & $\$ 123,355$ & $\$ 123,355$ & $\$ 150,230$ & $\$ 0$. & $\$ 123,355$ & 50 \\
\hline 17 & Controls Computor Packago & HONEYWELL. & A/30/93 & 583,442 & $\$ 97,001$ & $\$ 80,500$ & $\$ 13,559$ & $\$ 97,001$ & so \\
\hline 18 & Cooling Bod \& Economizer Tubes: & ALLEGHENY BOILER TUBE & 6/9/93 & $\$ 29,000$ & $\$ 29,000$ & * & s. & $\$ 29,000$ & so \\
\hline 19 & Ory lnloction Fabrle Fllter: Besthouso & AEROPULSE INC & $5 / 20 / 92$ & $\$ 130,376$ & $\$ 138,523$ & $\$ 161,250$ & $\$ 8,147$ & $\$ 136,511$ & $\$ 2,012$ \\
\hline 20 & Ducting \& Pliping & MeCluro & & $\$ 65,292$ & $\$ 249,495$ & 526,570 & $\$ 184,203$ & $\$ 136,004$ & $\$ 113,491$ \\
\hline 21 & Eloctrical Equpment \& installetion & DBG/Carpontor Engr & $2 / 3 / 94$ & $\$ 215,000$ & $\$ 279,348$ & $\$ 135,200$ & $\$ 34,348$ & $\$ 212,950$ & $\$ 56,398$ \\
\hline & Emlsslons Maniloring Equlpment & ENERTEC & $8 / 11193$ & $\$ 135,300$ & $\$ 135,300$ & $\$ 87,050$ & sol & $\$ 113,098$ & 522,202 \\
\hline
\end{tabular}


Table 10. Lebanon VA Project Equipment Costs

\begin{tabular}{|c|c|c|c|c|c|c|c|c|c|}
\hline 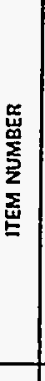 & EQUIPMENT & VENDOR & 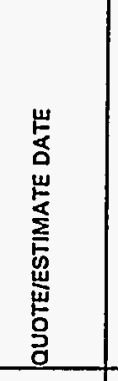 & 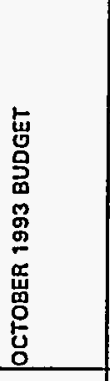 & 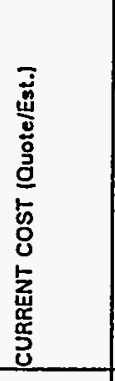 & 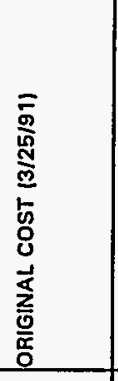 & 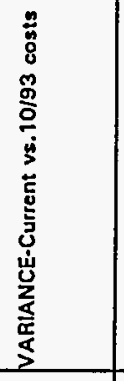 & 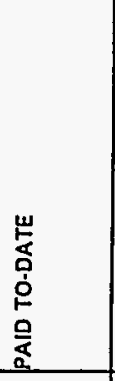 & 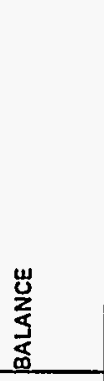 \\
\hline 23 & Emisslons Monitoring Equipment: Oxpoen & WAGREGORY \& CO & 9/3/93 & $\$ 6,119$ & $\$ 6,548$ & & $\$ 429$ & $\$ 6,548$ & so \\
\hline 24 & Expansion Join's & SENIOR FLEXONICS & $7 / 13 / 93$ & $\$ 26,099$ & $\$ 25,862$ & & (5237) & $\$ 25,862$ & so \\
\hline 25 & Fans \& Blowors: ACB \& LCB:- & SPENCER TURBINE & $11 / 13 / 91$ & $\$ 12,709$ & $\$ 13,060$ & $n$ & $\$ 351$ & $\$ 13,060$ & so \\
\hline 26 & Fans \& Blowers: Primary \& ID & ROBINSON & $7 / 113 / 93$ & $\$ 54,608$ & $\$ 54,608$ & $\$ 28,900$ & so & $\$ 54,608$ & so \\
\hline 27 & Flyash Roinjoction System & DONLEE $J O X$ VALVE & 12/5/91 & $\$ 14,290$ & $\$ 14,290$ & $\$ 41,600$ & s. & $\$ 9,031$ & $\$ 5,259$ \\
\hline 28 & Flyash Roinjoction System: Bed Mati Blowers & R.M.ASSC & $7127 / 93$ & $\$ 10,075$ & $\$ 10,025$ & & $(\mathbf{5 5 0 )}$ & $\$ 10,025$ & so \\
\hline 29 & Natural Gas lino moved & UGI & & so & so & s.o & so & so & \$o \\
\hline 30 & Hospital Wasto, Handllnge \& Sub-Systems & ESSEX CONVEYOR & $7 / 15 / 93$ & $\$ 31,010$ & $\$ 36,815$ & $\$ 72,800$ & $\$ 5,805$ & $\$ 36,815$ & so \\
\hline 31 & Instruments: Prossuro hadicalors/Transmiltors & DWYER/HONEYWELL & 9/10/93 & $\$ 2,500$ & $\$ 1,090$ & & $(\$ \$ 1, \Delta 10)$ & $\$ 1,090$ & $\$ 0$ \\
\hline 32. & Instruments: Prossuro Transmilters & HONEYWELL & 5/24/93. & $\$ 12,569$ & $\$ 12,569$ & $\$ 16,190$ & so & $\$ 12,569$ & so \\
\hline 33 & Instruments: Prossure Transmittors (Additiona) $\ldots$ & HONEYWELL & & so & $\$ 1,097$ & nat & $\$ 4,097$ & $\$ 4,097$ & so \\
\hline 34 & Instruments: Thermocouples & cos & $5 / 26 / 93$ & $\$ 4,347$ & $\$ 5,428$ & & $\$ 1,081$ & $\$ 5,428$ & so \\
\hline 35 & Insulation Malerials 8 installation & DONLEE & $5 / 26 / 93$ & $\$ 17,220$ & $\$ 17,220$ & $\$ 17,220$ & $\$ 0$ & $\$ 0$ & 517,220 \\
\hline 36 & Umostone Storsge, Handlling \& Fooding & MACAWBER SYSTEMS & $5 / 23 / 93$ & $\$ 60,881$ & $\$ 60,881$ & $\$ 72,800$ & so & $\$ 60,881$ & s. \\
\hline
\end{tabular}


Table 10. Lebanon VA Project Equipment Costs

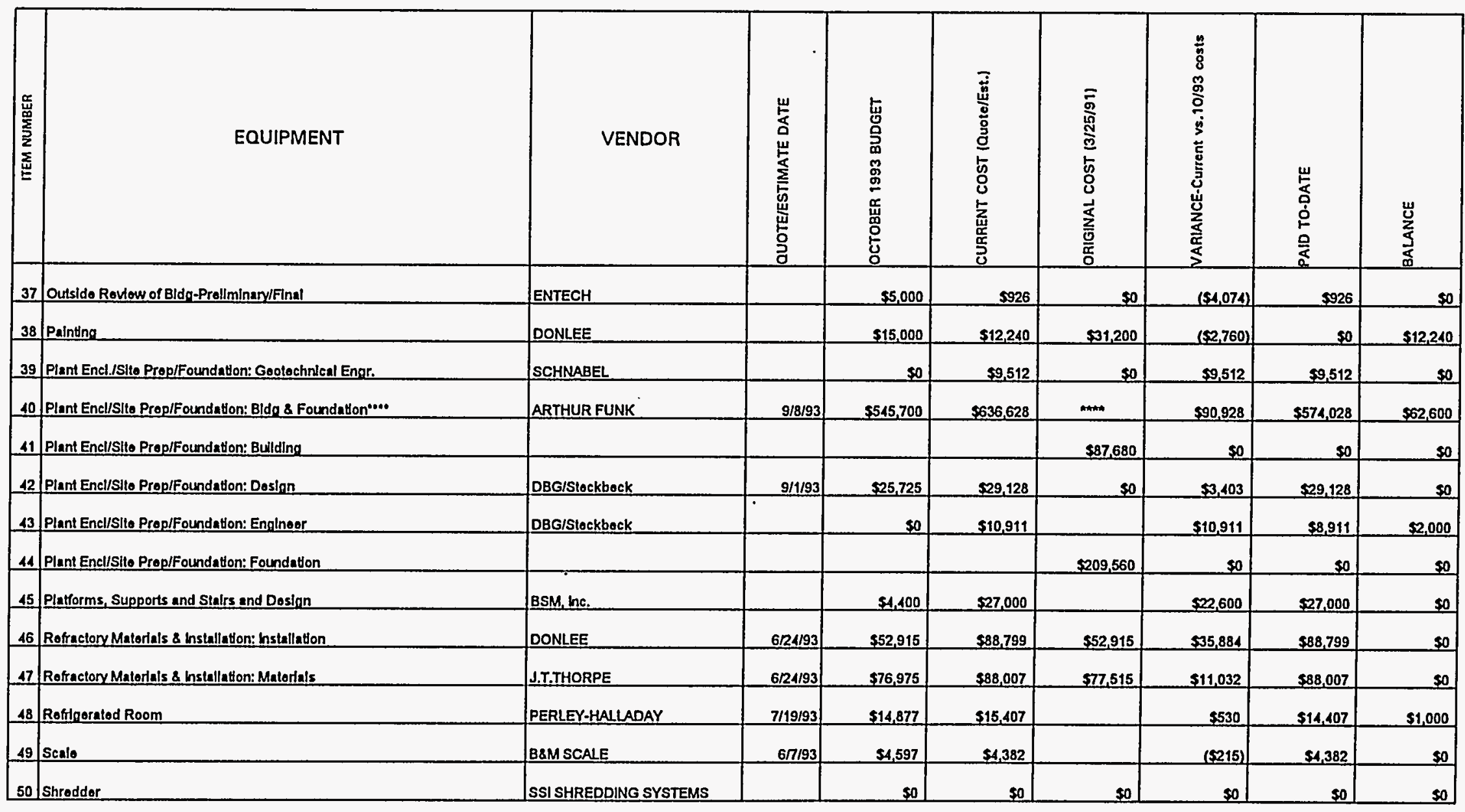


Table 10. Lebanon VA Project Equipment Costs

\begin{tabular}{|c|c|c|c|c|c|c|c|c|c|}
\hline 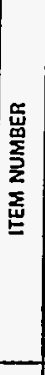 & EQUIPMENT & VENDOR & 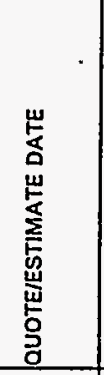 & 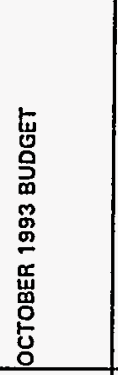 & 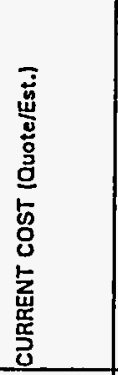 & 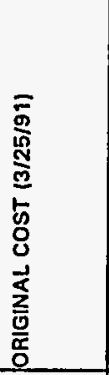 & 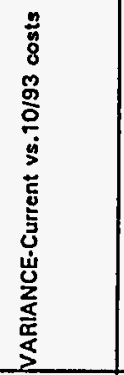 & 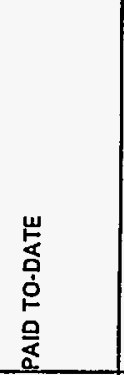 & 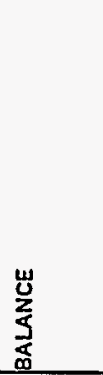 \\
\hline 51 & Shrodder Blower & ROBINSON & $126 / 93$ & $\$ 3,019$ & $\$ 3,140$ & & $\$ 121$ & $\$ 3,140$ & so \\
\hline 52 & Shroddor: Movo from York lo Sito & DONLEE & & $\$ 5,200$ & $\$ 5,200$ & $\$ 5,200$ & 50 & $\$ 5,200$ & so \\
\hline 53 & Slido Gales & ROVALVETTECHNAFLOW & $7 / 28 / 93$ & $\$ 52,461$ & $\$ 52,664$ & & $\$ 203$ & $\$ 52,665$ & so \\
\hline 54 & Soil Borings & Schnabol & & $\$ 5,850$ & $\$ 5,850$ & & so & $\$ 5,850$ & so \\
\hline 65 & Start-up Bumer & ECUPSENORKAIRE & $8 / 6 / 93$ & $\$ 9,242$ & $\$ 9,242$ & $\$ 5,230$ & so & $\$ 9,242$ & so \\
\hline 56 & Start-up Burnor (Mod. Motor) & HONEYWELL & $8 / 20 / 93$ & $\$ 266$ & $\$ 266$ & & so & $\$ 266$ & so \\
\hline 57 & Startup Bumer Panol & DONLEE & & 50 & $\$ 1,284$ & so & $\$ 1,284$ & $\$ 1,284$ & so \\
\hline 58 & Sloum Slloncor & MBRATION \& NOISE ENGR & $7 / 12 / 93$ & $\$ 3,415$ & $\$ 3,065$ & & $(5350)$ & $\$ 3,065$ & so \\
\hline 59 & Stoolwork or Equlpmont Support & DONLEE & & $\$ 72,290$ & $\$ 143,639$ & $\$, 15,430$ & 571,349 & $\$ 143,639$ & so \\
\hline 60 & Storllyzation System & DONLEE & $12110 / 91$ & $\$ 6,187$ & $\$ 6,187$ & & so & $\$ 1,650$ & $\$ 4,537$ \\
\hline 61 & Sterllization Tosting & DONLEE & & 57,000 & $\$ 888$ & & $(\omega 6,112)$ & 5888 & $\$ 0$ \\
\hline 62 & Transformer for Lob VA Equpment. & Blall 8 Myors & & $\$ 8,000$ & $\$ 49,100$ & & $\$ 11,400$ & $\$+9,400$ & $\$ 0$ \\
\hline 63 & Valvos \& Dampors & IPS & & $\$ 14,364$ & $\$ 26,065$ & $\$ 26,020$ & $\$ 11,701$ & $\$ 26,065$ & $\$ 0$ \\
\hline 64 & Vendor Equipment Installistion & AYCOCK & & $\mathbf{s} 194,930$ & $\$ 478,107$ & & $\$ 283,177$ & $\$ 394,837$ & $\$ 83,270$ \\
\hline
\end{tabular}


Table 10. Lebanon VA Project Equipment Costs

\begin{tabular}{|c|c|c|c|c|c|c|c|c|c|}
\hline 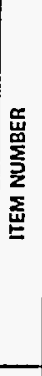 & EQUIPMENT & VENDOR & 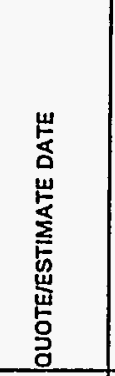 & 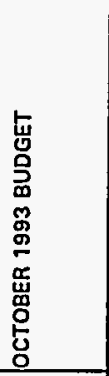 & 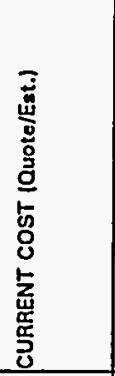 & 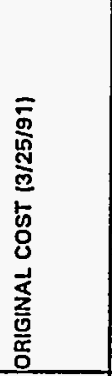 & 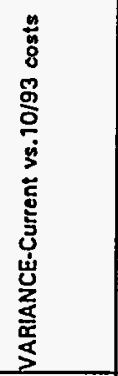 & 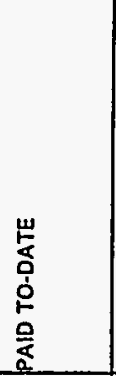 & 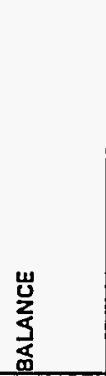 \\
\hline 65 & Computerlzed Portuble Analyzers & ECOMAmerica & & so & $\$ 4,638$ & & $\$ 4,638$ & $\$ 1,638$ & - so \\
\hline 66 & Additional paymonvperformance bonds & TBD & & so & so & & so & so & 50 \\
\hline 67 & Onslito rofrectory curo & Hotworks & Jul-95 & so & $\$ 6,950$ & & $\$ 5,950$ & so & $\$ 6,950$ \\
\hline 68 & Bonding and Grounding & TBD & & s. & $\$ 6,000$ & & $\$ 6,000$ & so & $\$ 6,000$ \\
\hline 69 & Sump pumps and controls & Reodon & • & so & $\$ 2,500$ & & $\$ 2,500$ & so & $\$ 2,500$ \\
\hline 70 & Stoum/Foodwator Valvos & IPS & $11 / 4 / 94$ & $\$ 0$ & $\$ 2,258$ & & $\$ 2,258$ & so & $\$ 2,258$ \\
\hline 71. & Shroddor Hydraulla Fillor & ssi ${ }^{\circ}$ & $11 / 3 / 94$ & $\$ 0$ & $\$ 421$ & & $\$ 421$ & s. & $\$ 421$ \\
\hline 72 & Ar Cennons & Airmatios & $11 / 16 / 94$ & so & $\$ 5.527$ & & $\$ 5,527$ & $\$ 5,527$ & $\$ 0$ \\
\hline 73 & Nolso Supprossion: Motor/Blowors & BRD Noisombration & $10 / 28 / 94$ & 50 & $\$ 1,288$ & & $\$, 288$ & $\$, 288$ & sol \\
\hline 74 & Hoattoss Afr Dryor & Ar Flow Co., he. & $12 / 8 / 94$ & so & $\$ 7,028$ & & $\$ 7,028$ & 57,028 & so \\
\hline 75 & Orfices and venturls & CIB/MES & $10 / 20 / 94$ & so & $\$ 12,932$ & so & $\$ 12,932$ & $\$ 12.932$ & 50 \\
\hline 76 & Cart for modical wasto & CONSOLIDATED PLASTIC CO & $12 / 15 / 94$ & so & so & & so & so & so \\
\hline 77 & Sito trallor rontal - 13 months & GE CAPITAL MODULAR SPACE & 12/15/94 & $\$ 0$ & $\$ 2,624$ & & $\$ 2,624$ & $\$ 1,872$ & 5752 \\
\hline 78 & Hout Tracing & DONLEE & $7 / 31 / 95$ & $\$ 0$ & $\$ 5,200$ & so & $\$ 5,200$ & sol & $\$ 5,200$ \\
\hline
\end{tabular}


Quarterly Progress Report

(August 1, 1995 - October 31, 1995)

Page 25

Table 10. Lebanon VA Project Equipment Costs

\begin{tabular}{|c|c|c|c|c|c|c|c|c|c|}
\hline 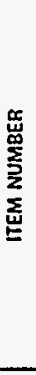 & EQUIPMENT & VENDOR & 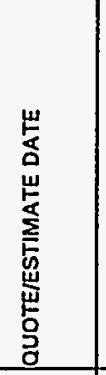 & 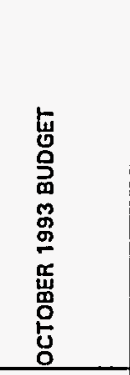 & 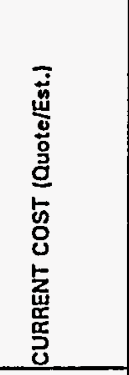 & 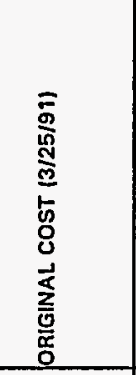 & 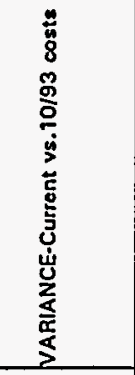 & 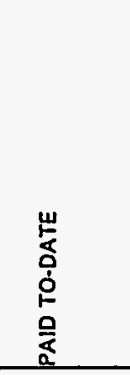 & 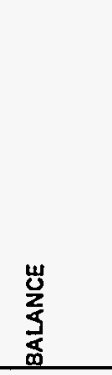 \\
\hline 79 & Added Usinging & DONLEE & $7 / 31 / 95$ & so & $\$ 14,500$ & so & $\$ 14,500$ & so & $\$ 14,500$ \\
\hline 80 & Sump Pump/Controls & RAEDEN & $111 / 16 / 94$ & $\$ 0$ & $\$ 2,500$ & $\$$ & 52,500 & so. & $\$ 2,500$ \\
\hline 81 & Cal Gasos and Regulators & SCOTT SPECAALTY & $12 / 15 / 94$ & so & $\$ 4,530$ & so & $\$ 4,530$ & so & $\$ 4,530$ \\
\hline 82 & Sink/Shower Doconoemination Stations & LAB SAFETY & 7/3/95 & so & $\$ 1,750$ & so & $\$ 1,750$ & $\$ 0$ & $\$ 1,750$ \\
\hline 83 & Sand for Bods & U.S.SILICA SAND & $9 / 23 / 94$ & so & $\$ 2,367$ & so & $\$ 2,367$ & so & $\$ 2,367$ \\
\hline 84 & Conl Pil Cover & DONLEE. & $713 / 95$ & so & $\$ 3,200$ & so & $\$ 3,200$ & $\$ 0$ & $\$ 3,200$ \\
\hline 85 & Grizzly Covor & DONLEE & 7/3/95 & s. & $\$ 4,800$ & s.o & $\$ 1,800$ & $s 0$ & $\$ 1,800$ \\
\hline 86 & Chomleal Foodwator Systom & Nutmer & $10 / 11 / 95$ & so & $\$ 1,305$ & so & $\$ 1,305$ & so & $\$ 1,305$ \\
\hline & PROJECT EQUIPMENT TOTALS & & & $\$ 2,822,612$ & $\$ 3,897,733$ & $\$ 1,889,040$ & $\$ 1,075,121$ & $50,403,088$ & $\$ 194,646$ \\
\hline
\end{tabular}

NOTES:

Tho cost of the cooling bed tubes was orlginally included in the

combustor/cyclono/cooling bed cost or $\$ 150,230$ (tom

tubo cost was orlginally Included in tio bollor cost of $\$ 58,050$ (ttom O).

- Tho cost of tho so blowers was orlginally included in the rans and blowers cost of \$28,900 (thom 26).

... The cost of tho additional prossure trensmittors is Ineluded in Hom 32.

... Tho cost of tho bullding and foundation originally Included itoms 11 and 14 at a cost of \$297,240. 


\section{Table 10. Lebanon VA Project Equipment Costs}

\section{NOTES:}

1. Items 1-28 and 30-64 were all part of the original October 1993 Budget.

2. Item 29 was added in March of 1994 prior to the start of the foundation.

3. Items 20,45 and 62 have been modified and approved after the equipment installation started.

4. Item 64 was formed from two previous items: "Vendor Equipment Installation" and "Vendor Equipment Installation: Rentals, etc." 


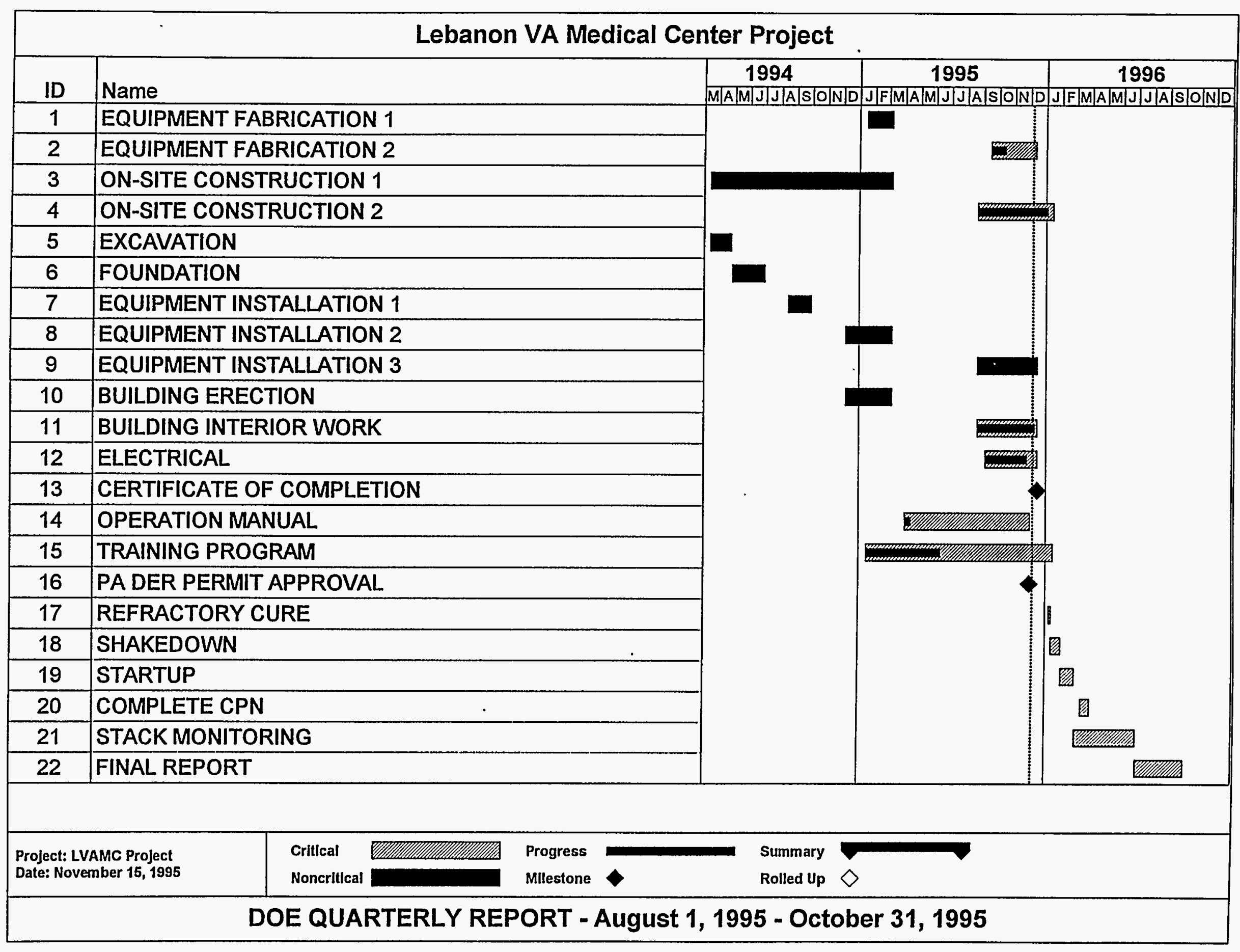

